\title{
ANALISIS PENGARUH RASIO SERABUT DAN CANGKANG KELAPA SAWIT SEBAGAI BAHAN BAKAR PADA BOILER
}

\author{
Kiagus Ahmad Roni ${ }^{1)}$, Elfidiah $^{1^{*)}}$, Yudha Widaputra ${ }^{1)}$,Dian Kharisma Dewi ${ }^{1)}$ \\ ${ }^{1)}$ Program Studi Teknik Kimia, Fakultas Teknik, Universitas Muhammadiyah Palembang \\ *email: gemaelfidiah@yahoo.com
}

\begin{abstract}
Abstrak
Serabut dan cangkang pada kelapa sawit merupakan limbah biomassa yang dihasilkan oleh pabrik pengolahan kelapa sawit, yang dapat digunakan sebagai bahan bakar pada boiler. Serabut kelapa sawit merupakan bagian kedua terluar dari biji sawit, yang berbentuk serabut. Sedangkan cangkang sawit berada di bagian ketiga terluar dengan tekstur keras yang menyelubungi kernel dari kelapa sawit. Cangkang kelapa sawit ini pada umumnya digunakan sebagai bahan bakar padat secara langsung atau sebagai bahan baku pembuatan briket. Tujuan dari penelitian ini yaitu untuk mengetahui nilai emisi gas buang dan nilai efisiensi pada boiler yang didapatkan dari bahan bakar serabut dan cangkang pada kelapa sawit. Metode yang digunakan adalah metode survey yang meliputi studi literatur, survey lapangan, uji laboratorium, dan analisa efesiensi boiler. Hasil penelitian menunjukan nilai Low Heating la/we (LHV) tertinggi 43805,04008 Kcal/Kg dan terendah dengan nilai 29862,98772 Kcal/Kg dengan rasio 70\% Serabut Kelapa Sawit dan 30\% Cangkang Kelapa Sawit mendapatkan nilai $36072,47322 \mathrm{Kcal} / \mathrm{Kg}$. Sedangk an nilai efisiensi boiler yang didapatkan yakni $80,11 \%$.
\end{abstract}

Kata Kunci: cangkang kelapa sawit, serabut, boiler, emisi gas buang

\section{PENDAHULUAN}

Kebutuhan energi listrik merupakan kebutuhan utama bagi kehidupan manusia saat ini baik dari kalangan industri, perkantoran, maupun masyarakat umum. Beberapa perusahaan di wilayah Sumatera Selatan telah melakukan beberapa langkah untuk memenuhi kebutuhan tersebut dengan menyiapkan Pembangkit Listrik yang bersifat sumber listrik utama maupun hanya membackup daya listrik yang disuplai PT. PLN untuk kegiatan oprasional seperti pada PT. Transpasipic Argo Industry Membangun PLTU yang memiliki kapasitas $1500 \mathrm{kVA} / 1200 \mathrm{~kW}$.

PT. Transpasific Agro Industry merupakan perusahaan yang bergerak dalam bidang pengolahan minyak kelapa sawit. Pabrik minyak kelapa sawit ini memiliki kapasitas terpasang 40 ton TBS (Tandan Buah Segar)/jam atau 600 Ton Perhari. Instalasi Pembangkit Listrik Tenaga Uap (PLTU) tersebut digunakan sebagai sumber energy listrik utama. Instalasi tersebut dibangun di lokasi pabrik yang terletak di Desa Upang Jaya, Kecamatan. Muara Telang, Kabupaten Banyuasin, Provinsi Sumatera Selatan. Cangkang dan serabut pada kelapa sawit adalah salah satu contoh bahan bakar padat yang digunakan pada Boiler. Bahan bakar ini merupakan keluaran ataupun output yang dihasilkan dari pengolahan pabrik kelapa sawit (Sunarwan, 2013). Serabut adalah bahan bakar padat yang bebentuk seperti rambut, serabut ini terdapat dibagian kedua dari buah kelapa sawit setelah kulit buah kelapa sawit. Sedangkan cangkang adalah sejenis bahan bakar padat yang berwarna hitam berbentuk seperti batok kelapa dan agak bulat, terdapat pada bagian dalam pada buah kelapa sawit yang diselubungi oleh serabut (Budiarto, 2009).

PT. Transpasific Agro Industry selaku perusahaan yang bergerak dibidang pengolahan kelapa sawit juga menggunakan limbah kelapa sawit untuk dapat dimanfaatkan menjadi bahan bakar boiler, namun perusahaan tersebut belum ada analisa mengenai rasio campuran antara serabut kelapa sawit dan cangkang kelapa sawit untuk mendapatkan komposisi yang tepat. Pada analisis sebelumnya (Rizky,2016) hanya membahas perbandingan rasio campuran serabut dan cangkang kelapa sawit yakni 
90\%:10\% dan 80\%:20\%. Agar penelitian lebih akurat, maka penulis menambahkan rasio analisi sebesar 70\%:30\% dan 60\%:40\%. Disamping itu juga penulis menambahkan analisis mengenai emisi gas buang pada boiler sesuai Peraturan Mentri Lingkungan Hidup dan Kehutanan Nomor. P.15/MENLHK/SETJEN/ KUM.1/4/2019 tentang Baku Mutu Emisi Pembankit Listrik Tenaga Termal (Parinduri, 2016).

Oleh sebab itu, dibutuhkan analisis pengaruh rasio serabut dan cangkang kelapa sawit sebagai bahan bakar pada boiler. Sehingga diperoleh rasio campuran bahan bakar serabut dan cangkang pada kelapa sawit yang baik untuk digunakan pada boiler, nilai efisiensi boiler yang didapatkan dari rasio campuran bahan bakar serabut dan cangkang pada kelapa sawit, serta nilai emisi gas buang pada boiler menggunakan dengan masih rasio campuran bahan bakar serabut dan cangkang pada kelapa sawit.

Boiler merupakan ketel uap bertutup dan memiliki tekanan, dengan panas dari pembakaran dikontakkan ke air sehingga terbentuklah air panas atau uap air (steam) (Djokosetyardjo,2006). Air panas atau steam yang bertekanan kemudian dimanfaatkan sebagai bahan bakar atau heater ke proses selanjutnya. Air yang dipanaskan hingga berubah fase menjadi steam, memiliki volume yang lebih besar berkisar 1.600 kali dari volume asal, dan menghasilkan tenaga seperti bubuk mesiu yang bersifat sangat mudah meledak. Jika ditinjau dari konversi energi, boiler berperan sebagai pengkonversi energi kimia yang terkandung didalam bahan bakar yang kemudian mengubahnya menjadi energi panas, dan selanjutnya digunakan sebagai bahan bakar atau pemanas (Archie, 1996).

Air yang digunakan sebagai bahan baku steam disebut dengan air umpan, yang biasanya berasal dari dua sumber, yaitu kondensat atau steam itu sendiri yang mengalami kondensasi. Syarat utama yang diperhatikan sebagai steam yaitu, air yang digunakan harus bersih dan terbebas dari logam. Air yang sudah diolah kemudian ditransfer ke deaerator dengan bantuan pompa. Didalam deaerator air kemudian dipanaskan kembali dengan bantuan uap sisa yang diperoleh dari hasil pemutaran turbin.

Jika ditinjau dari fluida yang mengalir, boiler dibagi menjadi dua yaitu boiler pipa api dan boiler pipa air. Perbedaan dari kedua tipe boiler ini terdapat pada kapasitas dan tekanan uap yang dihasilkan. Untuk boiler tipe pipa api menghasilkan kapasitas dan tekanan uap yang rendah, sedangkan untuk boiler tipe pipa air menghasilkan kapasitas dan tekanan uap yang tinggi (Imam, 2000).

Pemahaman mengenai karakteristik bahan bakar sangat berguna untuk menentukan kualitas bahan bakar tersebut sehingga perlu dilakukan tes laboratorium. Dalam hal ini pada pengujiannya proses pembakaran membutuhkan beberapa komponen bahan bakar yang disesuaikan berdasarkan ketersediaan bahan baku: seperti jumlah jenis bahan bakar berupa cairan, padatan maupun gas, berdasarkan cost (biaya), handling and storage (penyimpanan dan penanganan) dan sebagainya (Nazaruddin., 2017).

Pada penelitian ini menggunakan bahan bakar padat yang berupa cangkang serta serabut dari biji sawit. Bahan bakar padat pada umumnya merupakan produk samping dari perkebunan atau limbah dari pabrik yang mengolah hasil perkebunan seperti sawit sebagai contoh. Produk samping ini, jika tidak diolah akan menjadi limbah biomassa yang mencemari. Syarat utama limbah biomassa yang dapat digunakan sebagai bahan bakar, harus mengandung unsur karbon (C). Selain itu juga terdapat unsur nitrogen, hydrogen, belerang, abu, serta air (Alvian, 2019).

Boiler yang digunakan membutuhkan tiga macam bahan bakar dengan peran yang berbeda, yaitu solar sebagai pemicu proses pembakaran dengan persentase penggunaan sekitar $2 \%$, serabut kelapa sawit, serta cangkang kelapa sawit. 


\section{METODOLOGI PENELITIAN}

Penelitian dilaksanakan di Transpasific Agro Industri. Dengan penelitian ini dilakukan dengan metode survey. Setelah melakukan studi literarur dan survey lapangan dengan pengambilan sampel serabut dan cangkang kelapa sawit, proses yang dilakukan selanjutnya adalah uji nilai kalor dengan menggunakan alat bom kalorimeter. Hasil uji nilai kalor selanjutnya akan dihitung dan dianalisa nilai efisiensi boilernya. Pada Gambar 1 menjelaskan alur proses dari penelitian yang dilakukan.

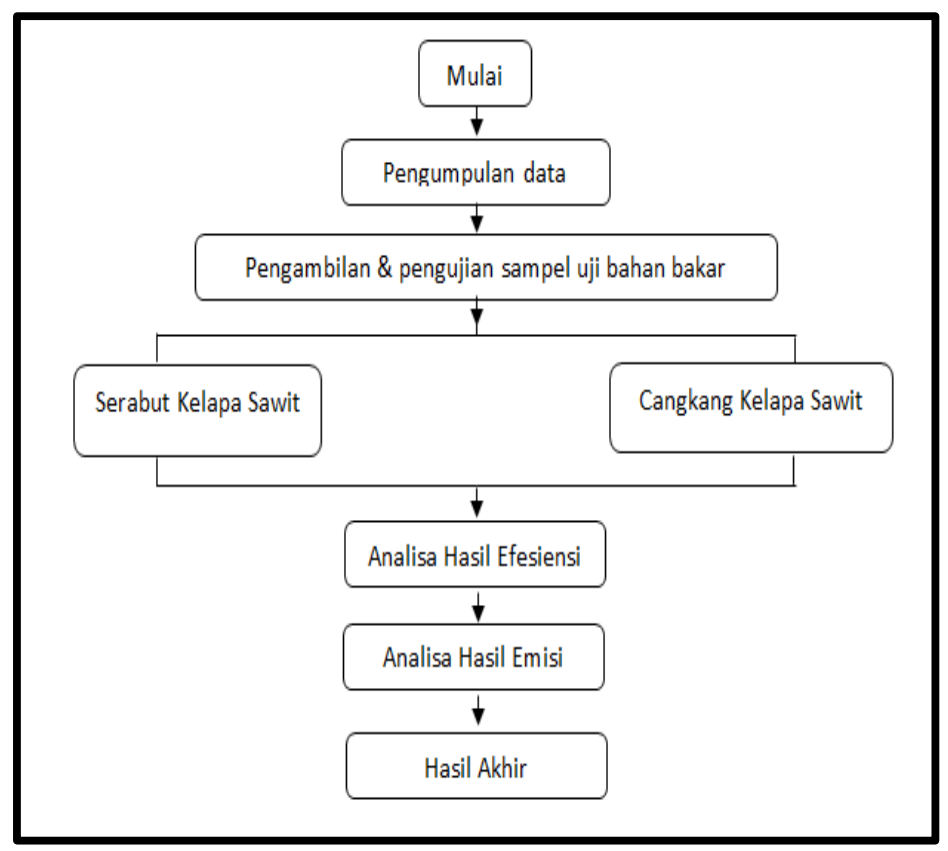

Gambar 1. Diagram Alir Prosses Penelitian

Dalam uji laboratorium hal pertama dilakukan adalah mencari nilai kalor bahan bakar menggunakan alat boom calorimeter. Bahan bakar yang dianalisa berupa serabut kelapa sawit murni $100 \%$, cangkang kelapa sawit murni 100\%, Campuran A dimana terdiri dari $90 \%$ serabut kelapa sawit \& $10 \%$ cangkang kelapa sawit, Campuran B dimana terdiri dari $80 \%$ serabut kelapa sawit \& $20 \%$ cangkang kelapa sawit, Campuran C dimana terdiri dari 70\% serabut kelapa sawit \& 30\% cangkang kelapa sawit, dan Campuran D dimana terdiri dari 60\% serabut kelapa sawit \& 40\% cangkang kelapa sawit. Perhitungan analisa menggunkan persamaan nilai panas, sebagai berikut :

$$
\begin{aligned}
& (\mathrm{HHV})=(\mathrm{T} 2-\mathrm{T} 1-0,05) \times \mathrm{Cv} \\
& (\mathrm{HLV})=\mathrm{HHV}-3240(\mathrm{~kJ} / \mathrm{kg}) \ldots
\end{aligned}
$$

Setelah dilakukannya uji bahan bakar menggunakan Boom kalorimeter, didapatkan hasil nilai T1 dan T2 pada setiap jenin bahan bakar dengan melakukan 3 kali perjobaan disetiap jenis bahan bakar. Setelah itu dilanjutkan dengan mencari nilai LHV (Low Heating Value) dan HHV (High Heating Value) menggunakan rumus nilai panas (Cengel, 1998).

\section{HASIL DAN PEMBAHASAN \\ Penentuan Nilai Rasio Low Heating Value (LHV)}

Kualitas bahan bakar sangat mempengaruhi kemampuan bahan bakar dalam menghasilkan energi. Sehingga hal tersebut menentukan jumlah nilai hasil pada proses pembakaran per satuan massa atau persatuan volume bahan bakar (Napitupulu, 2006). 


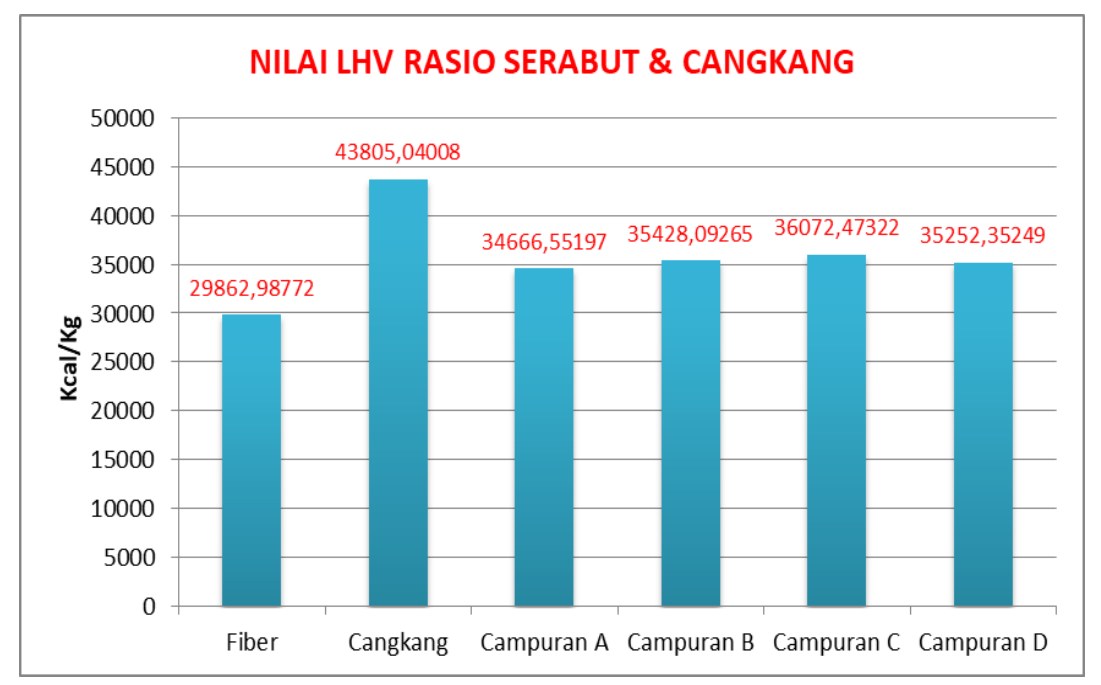

Gambar 2. Grafik perbandingan nilai LHV Rasio Serabut \& Cangkang

Berdasarkan grafik, dapat dilihat bahwa bahan bakar boiler memiliki nilai LHV yang berbeda-beda pada setiap jenis bahan bakar. Nilai LHV (Low Heating Value) tertinggi diperoleh bahan bakar boiler jenis cangkang kelapa sawit murni dengan nilai 43805,04008 Kcal/Kg dan nilai LHV (Low Heating Value) terkecil dimiliki oleh bahan bakar jenis serabut kelapa sawit murni dengan nilai 29862,98772 $\mathrm{Kcal} / \mathrm{Kg}$. serta nilai Low Heating Value terbaik untuk rasio kombinasi adalah pada campuran C yakni 70\% Serabut kelapa sawit \& 30\% Cangkang kelapa sawit dengan nilai 36072,47322 Kcal/Kg.

\section{Penentuan Efisiensi Boiler}

Metode yang digunakan untuk menentukan efisiensi boiler dalam penelitian ini adalah dengan menggunakan metode langsung atau dikenal sebagai metode input-output dengan memerlukan hasil output (steam) dan panas input sebagai bahan bakar untuk analisis nilai efisiensi serta penggunaan software chemicalloguc steamtab companion. Maka nilai efisiensi boiler yang digunakan pada rasio campuran $\mathrm{C}$ dengan persamaan rumus efisiensi boiler adalah $80,11 \%$.

$$
\text { Efisiensi Boiler }(\mathrm{y})=\frac{\mathrm{W}_{\mathrm{s}} \times \mathrm{h}_{3}-\mathrm{h}_{1}}{\mathrm{~W}_{\mathrm{f}} \times \mathrm{LHV}}
$$

Setelah nilai efisiensi boiler didapat dengan menggunakan rasio campuran C (70\% Fiber \& 30\% Cangkang), maka dilanjutkan dengan pengujian emisi boiler. Alat yang digunakan pada pengujian emisi pada boiler adalah Gas Emmisison Analyser, Atomic Adsorption Spectroscopy, Spektrofotometer UV VIS, \& Isokinetik particular matter (Yolanda, 2017). Untuk mendapatkan hasil yang cukup akurat, penulis melakukan tiga kali pengujian. Hasil yang didapat baik karena di bawah batas baku mutu. Hasil pengujian emisi gas buang pada boiler dengan menggunakan bahan bakar kombinasi $70 \%$ Fiber \& 30\% Cangkang adalah baik karena masih dibawah batas baku mutu lingkungan. 
Tabel 1. Hasil Uji Emisi Gas Buang Pada Boiler

\begin{tabular}{|l|c|c|c|c|c|}
\hline \multirow{2}{*}{ Parameter } & \multicolumn{3}{|c|}{ Hasil Uji Coba } & $\begin{array}{c}\text { Batas Ambang } \\
\text { Baku Mutu*) }\end{array}$ & Standar \\
\cline { 2 - 6 } & $\mathbf{1}$ & $\mathbf{2}$ & $\mathbf{3}$ & - & SNI 19.7117.12.2009 \\
\hline Isokinetic & 98.8 & 98.5 & 98,7 & 300 & SNI 19.7117.12.2009 \\
\hline Particulate & 182 & 194 & 192 & 30 & SNI 19.7117.11.2005 \\
\hline Opacity & $<20$ & $<20$ & $<20$ & 1 & SNI 19.7117.6.2005 \\
\hline $\mathrm{NH}_{3}$ & $<0.1$ & $<0.1$ & $<0,1$ & 600 & IK/OPS/LAB-SERCO/17 \\
\hline $\mathrm{SO}_{2}$ & 124 & 135 & 128 & 800 & IK/OPS/LAB-SERCO/16 \\
\hline $\mathrm{NO}_{2}$ & 146 & 152 & 149 & 5 & US-EPA Method 29 \\
\hline $\mathrm{HCl}^{*}$ & $<3$ & $<3$ & $<3$ & 5 & Bapedal 770/011/1996 \\
\hline $\mathrm{CL}_{2}$ & $<1$ & $<1$ & $<1$ & 8 & SNI 19.7117.9.2005 \\
\hline $\mathrm{HF}^{2}$ & $<0.1$ & $<0.1$ & $<0,1$ & - & ELECTROMETRIC \\
\hline $\mathrm{O}_{2}$ & 8.2 & 8.5 & 8,4 & - & ELECTROMETRIC \\
\hline Flow Rate & 28.5 & 27.2 & 27,5 & &
\end{tabular}

\section{KESIMPULAN}

Berdasarkan hasil analisa dan pengujian yang diperoleh bahwa cangkang kelapa sawit murni mendapatkan nilai Low Heating Value tertinggi tertinggi yaitu 43805,04008 Kcal/Kg sedangkan untuk nilai bahan bakar boiler yang terkecil dimiliki oleh serabut kelapa sawit murni dengan nilai $29862,98772 \mathrm{Kcal} / \mathrm{Kg}$. Sedangkan nilai Low Heating Value terbaik pada rasio kombinasi yakni pada kombinasi 70\% Serabut kelapa sawit \& 30\% Cangkang kelapa sawit dengan nilai 36072,47322 $\mathrm{Kcal} / \mathrm{Kg}$ dan didapatkan dengan hasil dibawah batas ambang \& baku mutu sesuai dengan standar yang telah ditetapkan. Maka semakin tinggi nilai LHV semakin sedikit juga jumlah bahan bakar yang digunakan, begitupun sebaliknya semakin rendah nilai LHV jumlah bahan bakarnya juga akan lebih banyak yang digunakan.

\section{DAFTAR PUSTAKA}

Archie. (1996). Prinsip-prinsip konversi energy. Jakarta: Erlangga.

Alvian, dkk. (2019). Studi Pemanfaatan Biomassa Limbah Padat Pabrik Kelapa Sawit (PKS) Untuk Pembangkit Energi Listrik. Jurnal Online Teknik Mesin Universitas Tanjungpura, Pontianak.

Budiarto, R. (2009). Potensi Limbah Pabrik Kelapa Sawit. Fakultas Teknik Universitas Sumatera Utara. Medan.

Cengel, Yunus. (1998). Termodinamika. Ed. 3. McGraw-Hill Inc.

Djokosetyardjo. (1993). Ketel Uap. Ed. 1, Jakarta: Pradnya Paramita. 
Djokosetyardjo. (2006). Ketel Uap. Ed. 6, Jakarta: Pradnya Paramita.

Imam. (2000). Cara perawatan \& pengoperasian ketel uap/boiler. Jakarta: Erlangga

Napitupulu, Farel H. (2006). Nilai Kalor (Heating Value) Suatu Bahan Bakar Terhadap Perencanaan Volume Volume Ruang Bakar Ketel Uap Berdasarkan Metode Penentuan Nilai Kalor Bahan Bakar Yang Dipergunakan. Bandung : Institut Teknologi Bandung

Nazaruddin. (2017). Optimasi Bahan Bakar Untuk Mengetahui Kinerja Boiler. Jurnal Online Teknik Mesin Sekolah Tinggi Teknologi Pekanbaru. 5 (2): 1-7.

Parinduri, Luthfi. (2016). Anilisa Pemanfaatan Biomasa Pabrik Kelapa Sawit. Jurnal teknologi listrik Vol.1 No.2

Rizky, FN. (2016). Analisa Pengaruh Kalor Bahan Bakar Fiber \& Cangkang Terhadap Efisisensi Boiler Pipa Air. ISSN 2087-3822. Jurnal Online Program Studi Teknik Mesin Fakultas Teknik Universitas Bandar Lampung. 6, 27-30.

Sunarwan, Bambang. (2013). Pemanfaatan Limbah Sawit untuk Bahan Bakar Baru dan Terbarukan. Jurnal Online, Vol. 7, No. 2, ISSN: 907-4964, Hal 1-14.

Yolanda P, dkk. (2017). Analisa Efisiensi Boiler Menggunakan Metode Langsung. ISSN $2337-$ 8204. Jurnal Online Fakultas MIPA Universitas Tanjung Pura, (1) : 09-12. 